\title{
THE EFFECT OF COLLABORATIVE ASSESSMENT AND LEARNING STYLE ON STUDENTS' WRITING COMPETENCY
}

\author{
Subawa, IM. \\ Program Studi Pendidikan Bahasa, Program Pascasarjana \\ Universitas Pendidikan Ganesha \\ Singaraja, Indonesia \\ e-mail: made.subawa@pasca.undiksha.ac.id \\ Nitiasih, N. P. K. \\ Program Studi Pendidikan Bahasa, Program Pascasarjana \\ Universitas Pendidikan Ganesha \\ Singaraja, Indonesia \\ kerti.nitiasih@pasca.undiksha.ac.id \\ Putra, I N.A. \\ Program Studi Pendidikan Bahasa, Program Pascasarjana \\ Universitas Pendidikan Ganesha \\ Singaraja, Indonesia \\ jaya.putra@pasca.undiksha.ac.id.
}

\begin{abstract}
This experiment study aims at investigating the effect of collaborative assessment and learning style on students' writing competency of eleventh grade students of SMAN 1 Kuta. To conduct this research, 92 students were selected as the sample. The design of this research was $2 \times 2$ factorial design. Data of writing competency were collected by an instrument called posttest which is essay type test, meanwhile learning style data were collected by questionnaire. The acquired data were analyzed statistically by two way ANOVA and Tukey test. This research discovers: 1) there is a significant effect of collaborative assessment on students' writing competency, 2) there is a significant interaction effect of assessment type (collaborative and conventional assessments) and learning style (field dependent and independent) on students' writing competency, 3) collaborative assessment affects significantly on field dependent students' writing competency, and 4) collaborative assessment does not affect significantly on field independent students' writing competency.
\end{abstract}

Keywords: collaborative assessment, learning style, students' writing competency

\section{INTRODUCTION}

The national education system of Indonesia is regulated by Law No. 20/2003 (Undang-Undang Republik Indonesia No. 20 Tahun 2003 tentang SISDIKNAS). It means that all education programs in each educational unit in Indonesia are managed under this law. Based on it, the goal of national education is as follows:

"Tujuan pendidikan nasional Indonesia adalah untuk berkembangnya potensi peserta didik agar menjadi manusia yang beriman dan bertakwa kepada Tuhan Yang Maha Esa, berahlak mulia, sehat, berilmu, cakap kreatif, mandiri dan menjadi warga negara yang demokratis serta bertanggung jawab." (UndangUndang Republik Indonesia (UURI) No. 20/2003)

The statement implies that national education develops holistically students' potency both in academic and non-academic. To achieve the goal, the Indonesian government has done innovative ways. One of them is by changing the curriculum into Competency Based Curriculum (CBC) and Kurikulum Tingkat Satuan Pendidikan (KTSP) or School Based Curriculum (SBC). Both of the curriculums emphasize on the changing of instruction paradigm. The instruction must direct the students to be active 
learners. By participating actively, the students can get meaningful learning experiences and feel the importance of their learning for their life.

Besides instruction paradigm, assessment paradigm is also changed. Through PERMEN Nomor 27 Tahun 2007, the government has established nine assessment principles, namely: valid, objective, fair, integrated, opened, comprehensive and continuous, systematic, criteria based, and accountable. Based on those criteria, the assessment used must clear criteria known by the students. Besides that the assessment should be implemented both during process and at the end of learning. By using clear criteria and concerning both on process and product of learning, the holistic information of students' competency can be known.

In SBC, English is one of the important subject which should be mastered by the students. It focuses on four language skills, namely: listening, reading, speaking, and writing. Besides the skills, teaching English also focuses on integrated skills, such as: grammar, structure, and vocabulary. Each skill has its standard and basic competencies that should be achieved by the students. The standard and basic competencies are taken from Ministry Regulation (PERMEN) No 22 about content standard. From here, the teachers can develop the indicators of learning per basic competency based on the potency owned by each unit of education.

Writing is one of skills which should be mastered by the students in EFL. Harmer (2007) states writing is productive skill where students actually have to produce language themselves. It means that the students have to produce pieces of writing products. According to Hamp-Lyon (1990) writing is a personal act in which writers take ideas or prompts and transform them into "self-initiated topic. Here, complex mental activity is needed to produce ideas and transform them into visible language. It is also supported by Flower \& Hayes (1981) who state that writing involves putting ideas into language (text generation) and then into written words (transcription) to build cohesive and coherent text. To transfer the ideas into text, microlanguage skill such as: grammar, structure, mechanic, punctuation, and vocabulary is needed. Briefly, writing integrates several processes, such as: finding topic, providing information to support the topic, classifying ideas, organizing ideas in logical sequence and implementing linguistic knowledge. In other words, the students need ample time to compose their ideas into writing product.

The complexity of writing process itself makes writing is the most difficult skill for L2 learners to master (Richards and Renandya, 2002). This condition tends to make the students frustrated or even failed in writing. It makes the English teacher selects innovative teaching method and assessment type which are appropriate to the nature of writing. By correct selection, students' learning is facilitated during the writing process. So that the students are motivated to write.

To know how teaching writing and writing assessment were conducted, an observation was done in the SMAN 1 Kuta. Based on the observation, it was known that teaching writing had applied process writing approach consisting of five stages, namely: brainstorming, drafting, editing, revising, and publishing. During the writing process, the teacher facilitated the students by providing chance for the students to consult if they have difficulties. Here, the students were given ample time to write. They were permitted to bring their writing home if they did not finish in the class. At the establsihed time, the students should collect their writing.

To score the students' writing, rubric was used by the teacher. The rubric is adopted from Petunjuk Teknis Penilaian Bahasa Inggris SMA/MA. The rubric covers both cognitive and linguistic components. It indicates that the rubric can measure the students' writing ability comprehensively. Ideally and theoretically, the teaching writing and writing assessment by using rubric are matched to the nature of writing.

However, the assessment did not administered ideally. In more detail investigation, it was found that the teacher mostly just assessed the linguistic components, such as grammatical structure, spelling, mechanic, and punctuation. The cognitive component was less taken to be accounted. As long as the students' writing could be understood, it was tolerated. If there were misspelling, scratch mark would be given on the mistake. Finally, the students' writing were returned so that the students could know their mistakes. From the teacher's daily report book, it was known that the students over than $80 \%$ got score higher than passing grade (80). However, when the students' writing were tried to score ideally by using 
the rubric the result was on the contrary. $75 \%$ of the students could not reach the passing grade. It seems that the ideas of writing were less trained in writing.

Then interview was done to the teacher on this writing assessment phenomenon. From the interview, it was discovered that three factors causing the rubric did not applied well, namely: working time, number of students, and National Examination. For certified teacher, they had to teach 24 hours in a week. It means that they teach 5 classes. If there were 40 students in each class, it can be imagined how hard the teacher's job is. Besides that, writing is not assessed in national examination. It makes the teacher more focused on reading and listening skills to be assessed well.

The problems direct to modify the writing assessment. One way which can be done is by involving the students during assessment process. This way can reduce teacher's burden in assessing the students' writing product. Besides that, there are two advatages of involving students during assessing. First, the feedback process is most effective when all the protagonists are actively involved in the process (Spiller, 2009). Second, the students can be more understand on the feedback given (Duncan, 2007).

Involving the students in assessment can be done by implementing self-assessment, peer assessment, and collaborative assessment (Falchikov, 2003). Gielen, Dochy, and Dierick 2003 state that there are two disadvatages of peer assessment, namely: (1) there is supposed to be an equal work load, not all members do their part and (2) Students generally initially question the ability of peers to assess their work, and the value of the feedback received. Meanwhile, Chan (2010) states there are three weaknesses of self-assessment, namely: (1) self assessment can be subjective because students may not be sincere and may even over-evaluate their own performance, (2) time consuming for students, and (3) students may not be familiar with the assessment criteria. Because of the weaknesses of both self and peer assessment, collaborative assessment was researched.

O'Malley and Valdez Pierce (1996) define collaborative assessment is as the involvement of students and teacher during assessing process. This assessment is done in conference session between the students and teacher. If students are actively involved in decisions about how to learn and what to learn and why they are learning, and are also actively involved in decisions about criteria for assessment and the process of judging their own and others' work, then their relationship to their studies will probably be qualitatively different from those students who are treated as recipients of teaching and who are the object of others' unilateral assessment (McConnell, 2002). This positive point of view is used as the basis to predict that collaborative assessment psotive effect on students' learning.

If performance assessment were implemented in writing, the teacher' burden can be reduced because of the students' involvement. In the implementation, this type of assessment is mostly used during process of writing especially in editing and revising stages of writing. before it, the students are divided into heterogenuous groups. Then, they mutually assess their friends' writing by using rubric gien previously. Next, the teacher opens conference to give chance for the students to confirm the result of their friends' assessment. Through this conference, the students-students and students-teacher interactions occur so that they can share and know immediately their strengths and weaknesses of their writing.

Besides researching on the effect of collaborative assessment, it is very important to research affective factor that also affects students' achievement in EFL. Here, learning style is selected. Many researchers believe that learning style also plays very important rules to achieve better outcome (learning achievement, as measured by the final examination score) for the students (Campbell and Johnstone, 2010).

Learning styles, as defined by Kemp and Ross (1998) are traits that refer to how individuals advance learning tasks and process information. In the same way, Keefe and Monk (1986) define learning styles as the characteristic cognitive, affective, and psychological behaviors that play as relatively stable indicators of how learners perceive, interact with, and respond to the learning environment. Assuming that a learning style exists (or is perceived to exist) and that it is a measurable object, then there should be a meaningful way to measure the style of an individual.

As far as collaborative assessment is concerned, this authentic kind of assessment has never been implemented in any classes in senior high schools, including in assessing the writing skill. For that reason, it is urgent to research collaborative assessment in order to know its effect on students' writing 
competency. Moreover, the learning style is also important to be accounted in implementing assessemnt type because the students have different style in learning which makes them comfortable to learn. So that, it can also be seen the interactional effect of assessment type and learning style on writing competency.

Based on the explanation about collaborative assessment, learning style, and writing competency, this study was aimed at: (a) identifying significant difference in writing competency between the students treated by using collaborative assessment and those treated by using the conventional assessment, (b) identifying interaction of assessment types (collaborative and conventional assessments) and learning style (field dependent and field independent) on students' writing competency, (c) identifying difference in writing competency of the field dependent students treated by using collaborative assessment and those treated by using the conventional assessment, (d) identifying difference in writing competency of the field independent students treated by using collaborative assessment and those treated by using the conventional assessment.

\section{METHOD}

To administer this research, Posttest Only Control Group with 2x2 factorial design was applied. There were 92 eleventh graders of SMAN 1 Kuta in the academic year 2013/2014 wer selected as the sample. To get the sample, random sampling technique was applied. Through lottery technique. IPA 3 and 4 were selected as experiment group and IPA 2 and IPA were selected as control group. Then, learning style questionnaire was distributed to the students to classify them into field dependent and field independent. Field dependent students are the students who get score $33-82$ and field independent students are the students who get $83-165$. Next, treatment was given for each group for 8 times meeting. Then, posttest was given to the students to get the the students' writing competency data. The collected data were then analyzed statistically.The data analysis involved descriptive and inferential analysis. Descriptive analysis aims at describing data by measuring mean and standard deviation. Meanwhile, inferential analysis aims at testing the hypothesis. Inferential analysis was done by using Two-Way ANOVA which is followed by Tukey test to know interaction effect.

\section{FINDING AND DISCUSSION}

The calculation of descriptive analysis measuring mean and standard deviation to 6 groups of data can be presented in the Table 1

Table 1 Sum of the Calculation of the Central Tendency and Dispersion

\begin{tabular}{ccc}
\hline Group & Mean & Std Dev \\
\hline CLA & 51.17 & 5.17 \\
CA & 48.43 & 4.97 \\
CLFD & 54.52 & 3.63 \\
CLFI & 47.83 & 4.26 \\
CAFD & 46.96 & 4.93 \\
CAFI & 49.9 & 4.65 \\
\hline
\end{tabular}

Notes:

CLA = Collaborative assessment

$\mathbf{C A}=$ Conventional assessment

FD $=$ Field dependent

$\mathbf{F I}=$ Field independent

Std dev $=$ standard deviation

Based on Table 1, it is known that (1) mean value of CLA is higher than CA, (2) mean value of CLFD is higher than CAFDM, and (3) mean value of CLFI is lower than CAFI. In term of standard 
deviation (SD) value, SD value of CLA is the highest value. It is followed by the value of CA, CAFD,CAFI,CLFI, and CLFD. However, this result can not be used to answer the research problems. To answer research problems, inferential analysis by Two-way ANOVA was applied. The result can be presented in table 2.

Table 2. Sum of the Results of Hypothesis Testing by Two-Way ANOVA

\begin{tabular}{ccc}
\hline Source & F & Sig. (Probability) \\
\hline Assessment (A) & 8.93 & 0.004 \\
Learning style (LS) & 4.16 & 0.044 \\
A*LS & 27.73 & 0.00 \\
\hline
\end{tabular}

To answer the first research question, it can be seen from the value of A (assessment type). From the table 2 , it is known the sig value or probability of 0.004 which is lower than 0.05 . It means that there is a significant difference in writing competency between the students assessed by using collaborative assessment and those assessed by using conventional assessment. Meanwhile, the fourth hypothesis is answered by looking the value of A*LS. From the table 2, it is known that the value of A*LS of 0.00 which is lower than 0.05. It means that there is a significant interaction effect on the implementation of assessment type (collaborative and conventional assessments) and learning style (field dependent and field independent) on students' writing competency.

Since there is an interaction, it is followed by further analysis by Tukey test for two groups which are compared. The result of Tukey test can be seen in the Table 3 .

Table 3. Sum of the Tukey test

\begin{tabular}{ccccc}
\hline No & Compared groups & Q & Q table & Conclusion \\
\hline 1 & CLFD with CAFD & 8.31 & 2.80 & significant \\
2 & CLFI with CAFI & 4.52 & 2.80 & significant \\
\hline
\end{tabular}

The result of the calculation shows that the value of Qcounted of 8,31; meanwhile Qcritical value is 2.80. If Qcounted is higher than Qcritical value, it means that Ho is rejected or H1 is received. From the result of the calculation, Qcounted is higher than Qcritical value. It means that there is a significant difference in writing competency of the field dependent students treated by using collaborative assessment and those treated by using conventional assessment. To know which group is better, it can be seen from the mean of both groups. The mean score of field dependent students assessed with collaborative assessment of 54,52 which is higher than mean score of field dependent students assessed with conventional assessment of 46,96. So, it can be concluded that collaborative assessment has better effect than conventional assessment for field dependent students' writing competency. Meanwhile, the calculation for FI group shows that the value of Qcounted of 4,52; meanwhile Qcritical value is 2.80. If Qcounted is lower than Qcritical value, it means that Ho is received or H1 is rejected. From the result of the calculation, Qcounted is higher than Qcritical value. It means that there is significant difference in writing competency of the field independent students treated by using collaborative assessment and those treated by using conventional assessment. Here, the mean score of writing competency of field independent students assessed with conventional method is higher than those assessed with collaborative assessment. It can be concluded that conventional assessment affects better than collaborative assessment for writing competency of field independent students.

Based on the result of hypothesis testing by two-way ANOVA, it was discovered that the assessment type implemented during teaching and learning process affected significantly toward students' writing competency of eleventh grade students of SMAN 1 Kuta in the academic year 2013/2014. It was proven 
by probability value of 0.004 which lower than 0.05 at $5 \%$ significant level $(\alpha=.05)$. Further analysis showed that the mean size score of students assessed by using collaborative assessment was 51.17; meanwhile the mean score of the students assessed with conventional assessment was 48.43. It means that the mean score of students assessed by using collaborative assessment is higher than those taught by conventional assessment. Based on the result of hypothesis testing and the analysis mentioned, it could be interfered generally that students' writing competency taught by process writing approach and assessed by collaborative assessment is better than those taught by process writing approach and assessed conventional assessment. It means that collaborative assessment implemented with process writing approach has positive effect on writing competency of eleventh grade students of SMAN 1 Kuta in the academic year 2013/2014.

The same finding was found by Sugrue (1998), Shindler (2002), and McDonnel (2002). Sugrue (1998) discovers that there is a strong correlation between students grouping in assessing and their learning achievement. It discovers that the low-ability students can learn from the high ability students and high ability students can perform better on the field of studying. It means that grouping assessment has positive correlation on students' achievement.

Meanwhile, Shindler (2002) tries to compares the effectiveness of collaborative assessment and traditional assessment. This research discovers that collaborative assessment has better effect than traditional individualistic assessment method. It is argued that the students can share and discuss certain problems that they face during assessing process.

Lastly, McDonnel (2002) discovers: (1) $94 \%$ of the respondents agree that the teacher should not do assessment alone, (2) 82 respondents state that applying collaborative assessment in e-learning is not complex, (3) nearly all students (94\%) think that collaborative assessment is a learning event as much as an assessment process.

Further analysis on the finding above indicated that writing competency is a process which occurs continuously. This process involves cognitive process. Cognitive process is as the result of brain activities which is shown by the ideas which are created and organized by the students and how the students express their ideas in a writing product. In addition, how the writer tranfers their ideas in words, sentences, and paragraphs are also as the result of cognitive process. In writing, the writer should produce certain products. Here, the students must be creative. The students' creativity in writing was indicated by the originality of the students' ideas. Creative students would produce new ideas that never exist before. In order to produce new ideas, they always investigate and reflect on the previous ideas and information to create new works in the future.

Collaborative assessment creates chance for students and teacher to evaluate students' work (O'Malley and Valdez Pierce,1996). Here, there is conference where the students can consult their problems during writing. At the same time, the teacher can give solution on the problems faced by the students. Besides that, the teacher can get authentic problems of students' learning. In the implementation, collaborative assessment is started by assigning the students to make group. Each group member assesses mutually their group member's work. Then, it is continued to conference with their teacher to check the validity of the assessment done by the students.

The learning situation created by collaborative assessment enables the students to have feedback from from their peer and teacher during teaching and learning process. Astin (1993) states that without such feedback, learning can be very slow, difficult, and under some conditions virtually impossible. Furthermore, Black, et al (2005) states that feedback is an essential part of formative assessment to assess students' writing competency. the feedback indicates the steps that should be done in their learning. By providing ample feedback, collaborative assessment enables students' learning to be accessible for the students.

Collaborative assessment creates open-ended learning environment so that the students will find a variety of ways in solving their problems. It means that there is no single correct answer is needed. In the implementation of collaborative assessment, performance tasks is uased. Sudiarta (2007) argues openended learning enables the students to develop their creative and productive thinking. It can be interfered collaborative assessment implemented enables the students to develop their creativity in creating new ideas and to maximize feedback to produce high quality writing products. 
Another conclusion from the result of hypothesis testing on the simple effect discovered that conventional assessment is inappropriate with the nature of teaching writing. Writing is viewed as an ongoing process so that assessment implemented in assessing writing should not merely concern on the product but also the writing process. In other words, it is concluded that conventional assessment focusing merely on the product does not contribute positively toward the writing competency of eleventh grade students of SMAN 1 Kuta in the academic year 2013/2014. Conventional assessment applied in writing does not match because this kind of assessment does not provide opportunities for the students to know their strengths and weaknesses immediately. It is because the assessment is just done at the end of learning.

Besides that, conventional assessment just gives less feedback during learning process. It makes writing is slow and difficult for the students. The students might be confused when they have problems during writing. Conventional assessment also does not provide chance for the students to do sharing, consultation, and discussion during learning process.

For further analysis, it is important to discuss whether the assessment approach implemented in writing was the only factor which affected students' writing competency. Borich (2007) states that learning style is a factor out of other affective factors that can influence students' achievement. Actually, there are types of learning style. However, this research just focuses on two learning style, field dependent and field independent.

The hypothesis testing done by Two-Way ANOVA discovers that there is a significant interaction between assessment type (collaborative and conventional assessments) and learning style (field dependent and field independent) on students' writing competency. It is proven by probability value of 0.000. It is means that there is opposite effect of assessment type and learning style on students' writing competency.

For field dependent students, it is discovered that their writing competency is higher when they are assessed with collaborative assessment than when they are assessed by conventional assessment. It is proven from the mean score of field dependent students assessed with collaborative assessment of 54.52 which is higher than mean score of field dependent students assessed with conventional assessment of 46.96.

Governor (1998) said that FD learners are in more need of social effort and external help in interpreting clues inserted in a particular learning task. The social effort is surely provided by collaborative assessment. When it is implemented in writing, the students assess their friends' work in group. During assessing, the students can have discussion and sharing with their friends. The students can learn from each other. Then, there is conference between the teacher and students. It makes high socialization among students and teacher occurs. This situation makes FD learners are comfortable to the situation created by collaborative assessment. So that, the FD learners are motivated to learn because learning environment is appropriate to their nature.

It is also supported by Skehan (1998). In the field of language learning, Skehan thinks (1998) that FD individuals are unlikely to be analytic, to perceive situations as wholes, rather than being analyzable into components, and more likely to depend on external frames of reference for making judgments and relying on other's opinions. They are thought to be sociable, person-oriented, and warm. To the extent that language development is aided by high-quality interaction, such learners are more likely to be naturally drawn through their person orientation and their comfort in interaction situation to maximize encounters in which they are likely to receive good quality, relevant input, and have opportunities to use language to express meanings. During the implementation of collaborative assessment in writing, high interaction occurs among students and teacher. Here, the students can recieved comments and suggestions for their writing, both from their peers and teacher. It makes FD learners like this situation which can motivate them to write.

During the implementation of conventional assessment, the students can not socialize during learning process. It is because the assessment is just done at the end of learning by the teaher. In writing, the students also work individually. This condition is disliked by the field dependent students because they like to have suggestions from their friends as material to write. In addition, the correction and score 
given to the students are also less appropriate for the students. Field dependent students tend to be happy when the assessment is done together. So, they can know their mistakes.

Second effect seen is the effect of collaborative assessment on writing competency of field independent students. For field independent students, it is discovered that the mean score of students' writing (mean $=47.83$ ) assessed by collaborative assessment is lower than the students assessed by conventional assessment $($ mean $=49.91)$. Further analysis in hypothesis testing by Tukey test proves $\mathrm{Q}$ value $=4.52$ is higher than the critical $\mathrm{Q}$ table value $=2.97, \alpha=.05$. It means that there is a significant difference in writing competency between the students assessed by collaborative assessment and those assessed by conventional assessment. Since the mean score of FI assessed by conventional assessment is higher than those assessed by using collaborative assessement, it can be concluded that conventional assessment affect better than collaborative assessment on FI students' writing competency.

FI learners have been referred to as analytical, competitive, individualistic, task oriented, internally referent, intrinsically motivated, hypothesis testing, self-structuring, linear, detail oriented, and visually perceptive (Hall, 2000). Conventional assessment creates classroom condition where the students work individually to finish task assigned. FI does not need interaction during learning process. In the context of writing, they do not share and discuss their writing to their friends. It is because they tend to be individualistic and detail oriented. If they had problems, they do high effort to solve it because FI is intrinsically motivated.

$\mathrm{Hu}$ (1998) observed that FI learners rely less on external clues than their FD counterparts. FI learners, it appears, are more able to generate and structure their own knowledge rather than accepting knowledge reprocessed by others. Conventional assessment does not provide chance where the other students have correction or feedback during learning. It is because the assessment is done by the teacher at the end of learning. So, during writing process the FI learners have to find the solution by themselves by thinking critically. This is better for than receiving comments from their friends. It makes FI learners are comfortable to be assessed with conventional assessment.

$\mathrm{Hu}$ (1998) confirms that FI is less approprite to be assessed by using collaborative assessment. Collaborative assessment creates learning condition where the students interact mutually with their friends. Through the interaction, it is hoped that the students can learn from each other and enlarge their knowledge. However, this condition is disliked by FI. Because FI prefers to work alone than in group.

\section{CONCLUSION}

Based on the result of hypothesis testing, there are four conclusions that can be made. First, there is a significant difference in significant difference in writing competency between the students treated by using collaborative assessment and those treated by using conventional assessment. It is proven by probability value of 0,004 which is lower than 0,05 . The mean score of the students assessed with collaborative assessment was 51,17; meanwhile the mean score of the students assessed with conventional assessment was 48,43. It means that the students' writing competency assessed with collaborative assessment is higher than those assessed with conventional assessment. Second, there is a significant interaction effect of assessment type (collaborative and conventional assessments) and learning style (field dependent and field independent) on students' writing competency. It is proven by the probability value of 0,000 . Third, there is a significant difference in writing competency of the field dependent students treated by using collaborative assessment and those treated by using conventional assessment. It is proven by the value of Qcounted of 8,31 which higher than Qcritical of 2,80. The mean score of field dependent students assessed with collaborative assessment of 54,52 which is higher than mean score of field dependent students assessed with conventional assessment of 46,96. It can be concluded that collaborative assessment has better effect than conventional assessment for field dependent students' writing competency. Fourth, there is significant difference in writing competency of the field independent students treated by using collaborative assessment and those treated by using conventional assessment. It proven by the Qcounted of 4,52 which higher than Qcritical of 2,80. Here, the mean score of writing competency of field independent students assessed with conventional method is higher than those assessed with collaborative assessment. It can be concluded that conventional 
assessment affects better than collaborative assessment for writing competency of field independent students.

Furthermore, based on the finding and conclusion, there are three suggestions suggested. First, collaborative assessment can be tried as alternative assessment in teaching writing. It is because the nature of writing itself as on going process which is matched with the nature of collaborative assessment which focuses on both process and product of learning. Second, in collaborative assessment, the group should be heterogenous so poor students can learn from the good students and the good students can learn from the poor students' mistakes. Third, it is important to know the students' learning style. By knowing it, the teacher can create learning situation which are appropriate for the students' learning in the classroom.

\section{REFERENCES}

Badan Standar Nasional Pendidikan. 2005. Standar Kompetensi dan Kompetensi Dasar Bahasa Inggris $S M A / M A$. Jakarta: BSNP

Black, et.al.2005. Assessment for Learning: Putting into Practice. New York: Open University Press

Borich, Gary D.2007. Effective Teaching Methods.New Jersey: Pearson Prentice Hall.

Campbell, V. and Johnstone, M. 2010. The significance of earning style with respect oachievement in first year programming students.pdf (accessed on October 12 2012)

Chan C.2010. Assessment: Self and Peer Assessment, Assessment Resources@HKU, University of Hong Kong . Retrieved on 14 April 2014 at http://ar.cetl.hku.hk

Duncan, N. 2007. "Feed-forward": improving Students Use of Tutor Comments, Assessment \& Evaluation in Higher Education. 32 (3), 271-283.

Falchikov, Nancy. 2003. Involving students in assessment. Psychology Learning and Teaching, 3(2), $102-108$

Flower, L. S. and Hayes, J. R. 1981. A Cognitive Process Theory of Writing. College Composition and Communication, 32 (4), 365-387.

Gielen, S., Dochy, F., Onghena, P., Stuyven, K., Smeets, S. 2011. Goals of Peer Assessment and Their Associated Quality Concepts. Studies in Higher Education, 36(6). 719-735.

Governor, D. 1998. Cognitive styles and metacognition in Web based instruction. Retrieved October 30, 2013, from http://www.members.cox.net/vogannod/THESIS.html

Hall, J.K. 2000. Field dependence-independence and computer-based instruction in geography. (Unpublished doctoral dissertation, Virginia Polytechnic Institute and State University, Blacksburg, VA.

Hamp-Lyons, L.1990. Second Language Writing: Assessment Issues. In B.Kroll, ed., Second Language Writing: Research Insights for the Classroom. Cambridge: Cambridge University Press

Harmer, Jeremy.2006. The Practice of English Language Teaching. Cambridge: Pearson Longman 
Hu, J. 1998. The relationship between hypermedia features and the learning style/cognitive control of hypermedia developers. (Unpublished doctoral dissertation, West Virginia University, Morgantown, WV.). Available online from the West Virginia University Web site: http://etd.wvu.edu/templates/showETD.cfm?recnum=691. Last date accessed: October 30, 2004.

Keefe, J.W. and Monk, J. S. 1986. Learning style profile examiners' manual. Reston, VA: National Associationg of Secondary School Principals.

Kemp, J. Morrison, G. and Ross, S. 1998. Designing effective instruction. New York: Macmillan College Publishing Company.

Marhaeni, A.A.I.N. (2005). Pengaruh Asesmen Portofolio dan Motivasi Berprestasi terhadap Kemampuan Menulis Bahasa Inggris. Jakarta: State University of Jakarta (unpublished dissertation)

McConnel, David.2002. The Experience of Collaborative Assessment in e-Learning. Studies in Continuing Education, Vol. 24, No. 1.Carfax publishing

O’Malley, J.M and Valdez Pierce, L. 1996.Authentic Assessment for English Language Learners. New York: Addition-Wesly Publishing Company.

Richard, Jack C and Willy A. Renandya.2002. Methodology in Language Teaching: An Anthology of Current Practice. Cambridge: Cambridge University Press

Shindler, John V.2002. Examining the Soundness of Two Collaborative Assessment Practices in Teacher Education Courses. A paper presented at the Annual Meeting of the American Educational Research Association, New Orleans, LA, April, 2002

Skehan, Peter. 1998. A Cognitive Approach to Language Learning. Shanghai: Shanghai Foreign Language Education Press.

Sudiarta, I Gusti Putu.2007. Prospek Pengembangan dan Penerapan Model Pembelajaran Matematika Berorientasi Pemecahan Masalah Open-Ended di Sekolah Dasar di Propinsi Bali. Jurnal Pendidikan dan Kebudayaan 068,13.

Sugrue, Brenda.1998. Equity Issues in Collaborative Assessment: Group Composition and Performance. CSE Technical Report: The Regent of the University of California. 